UDC 551.513.11:551.510.534
A. V. Grytsai ${ }^{1}$, G. P. Milinevsky ${ }^{1,2,3, ~ *, ~ O . ~ I . ~ I v a n i g a ~}{ }^{1}$
1 Taras Shevchenko National University of Kyiv, Kyiv, Ukraine
2 State Institution National Antarctic Scientific Center, Ministry of Education and Science of Ukraine,
16 Tarasa Shevchenka Blvd., Kyiv, 01601, Ukraine
${ }^{3}$ College of Physics, International Center of Future Science, Jilin University,
Qianjin Street 2699, Changchun, 130012, P.R. China
* Corresponding author: genmilinevsky@jlu.edu.cn, genmilinevsky@gmail.com

\title{
TOTAL OZONE OVER VERNADSKY ANTARCTIC STATION: GROUND-BASED AND SATELLITE MEASUREMENTS
}

\begin{abstract}
Objective. Provide an analysis of the total ozone variations over Vernadsky Antarctic station (Faraday Base until 1996) from long-term ground-based and satellite series. Study the discrepancies between the data of different instruments. Methods. Data visualization followed by analysis, statistical treatment of the Vernadsky Dobson spectrophotometer observations and satellite total ozone series. Results. Satellite and ground-based measurements of total ozone over Vernadsky station have confirmed the stabilization in the ozone layer in the stratosphere over Antarctica from the early 2000s. British Faraday Base observations have retrieved an ozone spring maximum during the 1950s-1970s with a sharp decrease in the August-October values in the 1980s-1990s. That changed substantially total ozone seasonal cycle. Satellite overpasses and model data based on satellite measurements have been analyzed. It is shown that typical discrepancies between the Ozone Monitoring Instrument (OMI) model and the Vernadsky Dobson daily means are mainly in the range of 20 DU. Larger deviations are rare and are observed predominantly on the beginning and at the end of the observational season. Seasonal means and standard deviations for the model-Dobson differences were calculated that demonstrates worse correspondence of the OMI model with Vernadsky Dobson data during separate years, in particular 2009-2010. Conclusions. Both Dobson and satellite ozone data over Faraday/ Vernadsky station have shown the total ozone decrease during the 1980s-1990s (mainly in spring) with a following stabilization since year 2000. Comparison between the ground-based data and models calculated from satellite measurements indicates better correspondence of the Dobson and GOME2 results relatively the OMI ones. There are evidences that individual Dobson measurements underestimate to some degree total ozone on the beginning of observational season at high solar zenith angles and the low total ozone values.
\end{abstract}

Keywords: total ozone, Vernadsky Antarctic station, Dobson spectrophotometer, satellite measurements, data comparison.

\section{INTRODUCTION}

Total ozone content (TOC) in the Antarctic Region has been retrieved from ground-based observations started in the 1950s. TOC is traditionally measured in Dobson Units (DU); 1 DU corresponds to a gas layer with thickness in $0.01 \mathrm{~mm}$ under normal atmosphere conditions (temperature $0{ }^{\circ} \mathrm{C}$ and atmospheric pressure $1013 \mathrm{hPa}$ ); this is equal to $2.69 \cdot 10^{20} \mathrm{O}_{3}$ molecules per $\mathrm{m}^{2}$. The observations with Dobson spectrophotometer were begun at the British Antarctic Sur-

(C) A. V. GRYTSAI, G. P. MILINEVSKY, O. I. IVANIGA, 2018 vey (BAS) Faraday station located on Galindez Island near western shore of the Antarctic Peninsula. Later, in 1996 the Faraday station was transferred to Ukraine and renamed as Akademik Vernadsky (hereinafter referred to as Vernadsky station). Among several scientific studies, measurements of total ozone content were prolonged and now they have yet covered time span nearly 60 years (Kravchenko et al., 2009). Note that observations at Halley and Faraday (BAS) served to the ozone hole discovery in the mid1980s (Farman et al., 1985).

Negative trends in total ozone levels were largest during the 1980s-1990s (Solomon, 1999) with the 
following ozone stabilizations and signs of the forecasted recovery (Kuttippurath et al., 2013; Siddaway et al., 2013, Chipperfield et al., 2017). Minimal total ozone values close to 100 DU are observed in the inner part of the stratospheric polar vortex around the South Pole. Intensity of the polar vortex is determined by dynamical factors, in particular planetary wave activity (Waugh and Randel, 1999). High planetary wave activity results in the polar vortex edge deformation that is accompanied by strong (up to 150-200 DU) variations in total ozone content. These events are regularly observed at the Vernadsky station as well. Typically, the vortex is preserved to late November or December consisting in the polar air masses that are poor by ozone. After the polar vortex destruction, mixing the polar and moderate air causes increase in ozone levels. Consequently, dynamical processes are significant for total ozone interannual variations and chemical processes determine its long-term changes (Chipperfield et al., 2018), which is very important for prediction of ozone layer recovery.

Almost continuous satellite total ozone observations have been provided from the end of 1978. First long-term ozone data series were obtained with Total Ozone Mapping Spectrometer onboard the Nimbus-7 satellite (Stolarsky et al., 1986). Satellite observations have a clear advantage in Earth's surface coverage. The satellite observations are usually realized in the near-ultraviolet spectral range similarly to the ground-based Dobson and Brewer measurements. Respectively, their data do not cover the polar night areas. The TOC values obtained under high solar zenith angles have a restricted quality. Ground-based instruments also exhibit large errors under those conditions due to low intensity of ultraviolet light (Basher, 1982). As a result, the intercomparison between satellite and ground-based ozone data series is necessary to retrieve reliable values (Fioletov et al., 2008).

In our work, both individual and averaged groundbased data from Vernadsky station have been considered. They have been compared with individual satellite measurements (http://www.temis.nl/protocols/ O3total.html, Veefkind et al., 2006) and with model TOC data calculated from satellite observations (http://www.temis.nl/protocols/O3global.html, Es- kes et al., 2003), respectively. Mainly, TOC data of the Ozone Monitoring Instrument (OMI) onboard the Aura satellite platform from 2005 till 2017 is used. Besides, the SCIAMACHY/Envisat measurements (2002-2011, (Gottwald, 2006)) and GOME2 data from MetOp-A (2006-2017), and MetOp-B (20122017) satellites are considered as well (Subsections 3.2, 3.3). In all the cases, total ozone models with 6-hour step calculated for Vernadsky station from measurements of a single instrument were taken for processing. For OMI data, individual measurements close to Vernadsky station are also analyzed (Subsection 3.4). The analysis was realized for the Dobson spectrophotometer observations under different conditions (Direct Sun, Zenith Blue and Zenith Cloud types). In principle, using SCIAMACHY, GOME2, and OMI data is common to estimate tendencies in total ozone during last years (Chipperfield et al., 2018).

Long-term variations in the total ozone level over the Faraday/Vernadsky station have been estimated as well. Main attention was paid to spring season (September-November in the Southern Hemisphere) when minimal total ozone is observed over the Antarctic Region. Spring ozone decrease was followed by stabilization in the ozone layer, which begins from the early 2000s according to long-term data. This tendency is evident both from groundbased and satellite observations. Minimal TOC values over the Vernadsky station exist during the ozone hole conditions, in September-October. They reach 150 Dobson Units (DU) and sometimes are below that value. A threshold value for ozone hole conditions is equal to $220 \mathrm{DU}$.

\section{DATA. TOTAL OZONE MEASUREMENTS OVER FARADAY/VERNADSKY STATION}

Total ozone measurements at the British Faraday Antarctic station $\left(65.25^{\circ} \mathrm{S}, 64.27^{\circ} \mathrm{W}\right)$ started from 1957. Only Dobson spectrophotometers (No. 051, 073, 031, 103, and 123) were used for the measurements during the past six decades. Faraday/Vernadsky station ozone data are presented on the World Ozone and Ultraviolet radiation Center (http://woudc.org); monthly values are available on the British Antarctic 

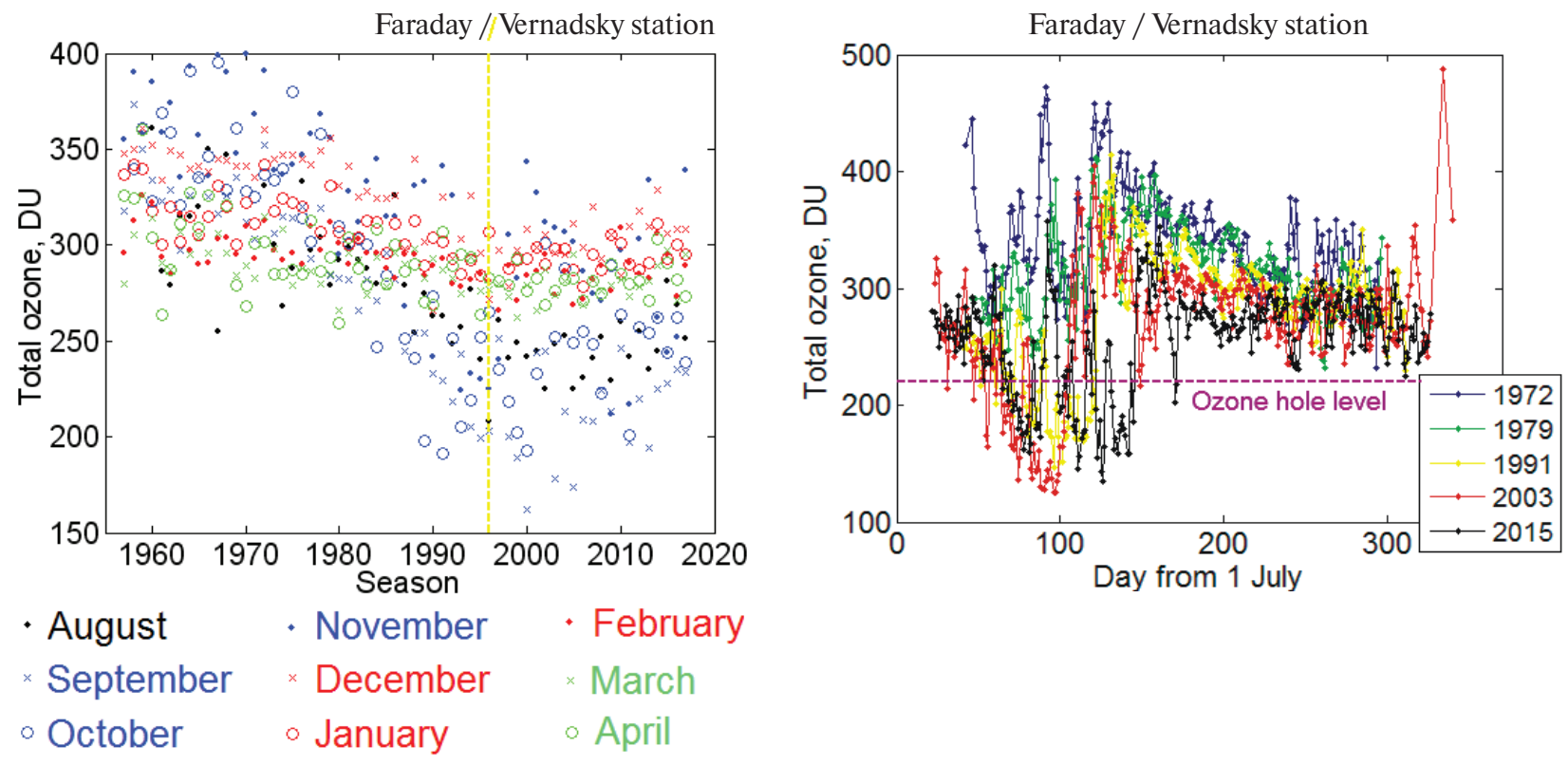

Fig. 1. Results of the ground-based measurements with Dobson spectrophotometer at Faraday / Vernadsky station: (left) monthly total ozone values; (right) total ozone variations during several observational seasons

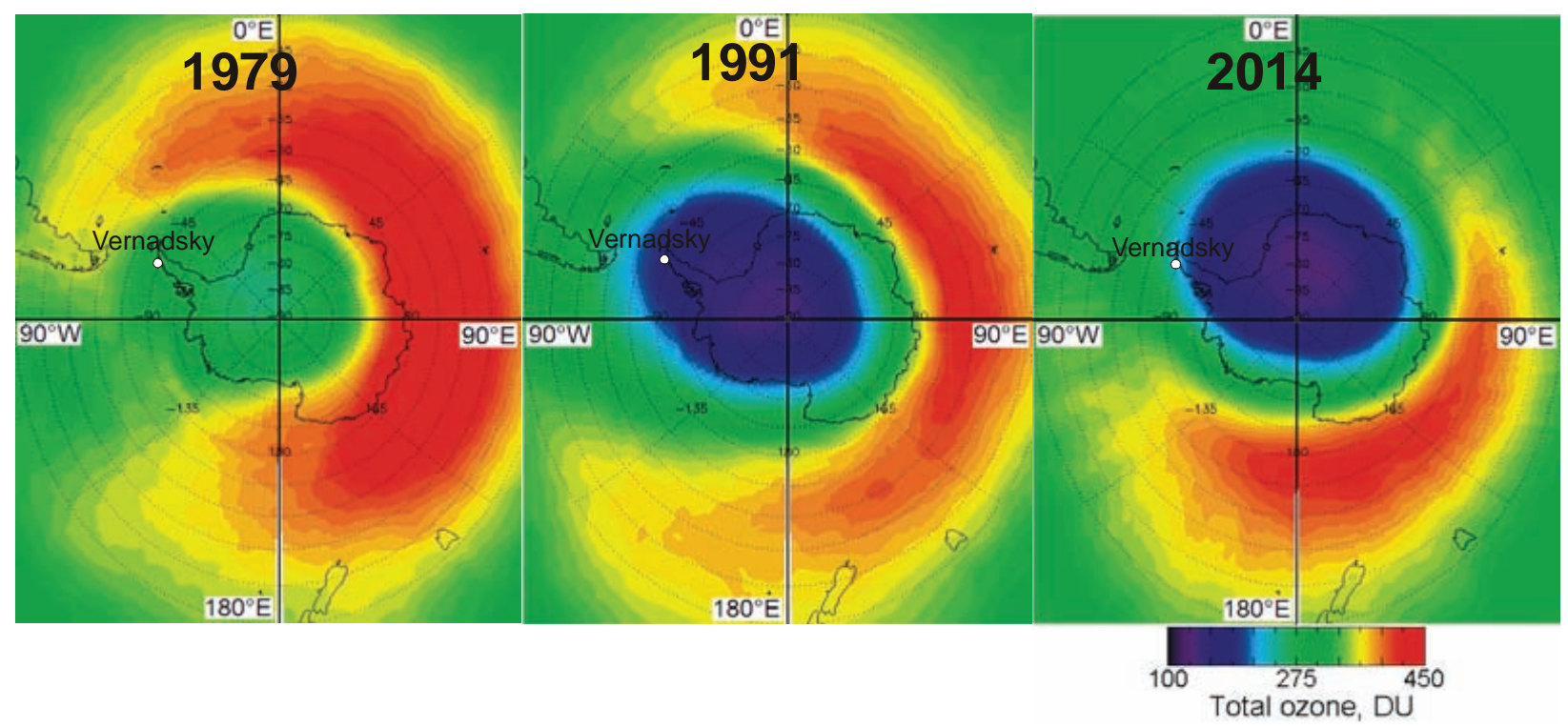

Fig. 2. October total ozone distribution at the high southern latitudes in 1979, 1991, and 2014

Survey's site (https://legacy.bas.ac.uk/met/jds/ozone/ index.html). The observational season lasts during nearly ten months between late July and late May. Extremely high solar zenith angles around June solstice are critical obstacle to retrieve total ozone levels using near ultraviolet radiation. Consequently, mon- thly values are analyzed only for the August-April time range (nine calendar months).

Before the late 1970s, seasonal cycle of total ozone in the Antarctic Region had shown maximal values during spring season (September-November in the Southern Hemisphere, Fig. 1). All monthly total ozone levels 
Vernadsky station, Direct Sun, 2016-2017

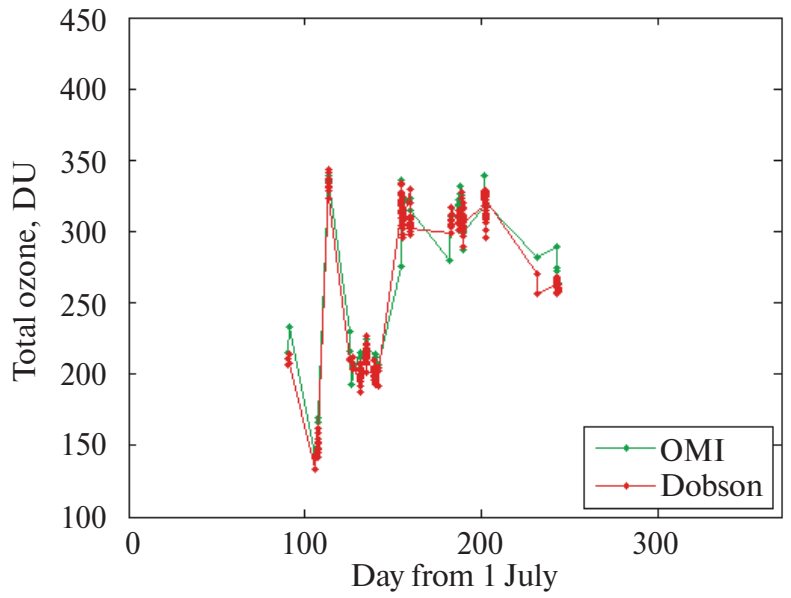

Vernadsky station, Zenit Cloud, 2016-2017

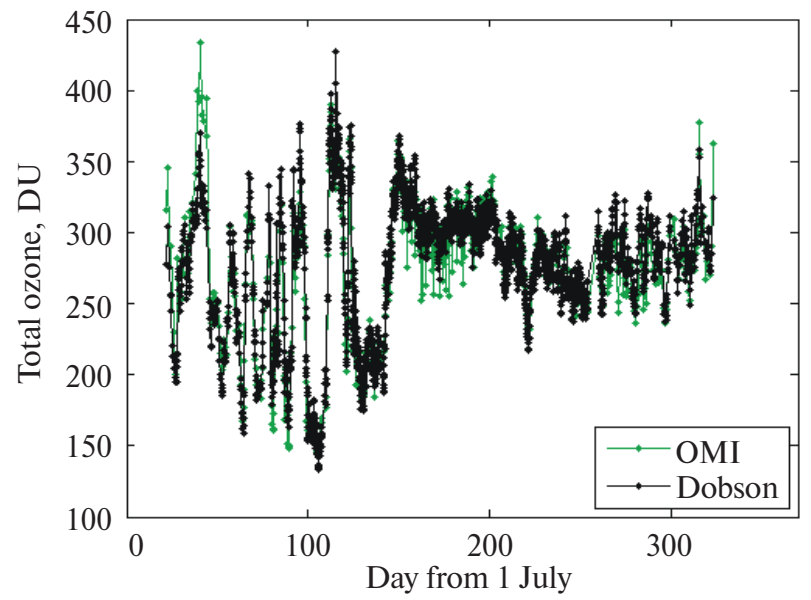

Fig. 3. Total ozone at Vernadsky station during the 2016-2017 observational season. Individual Dobson measurements and OMI overpasses are used
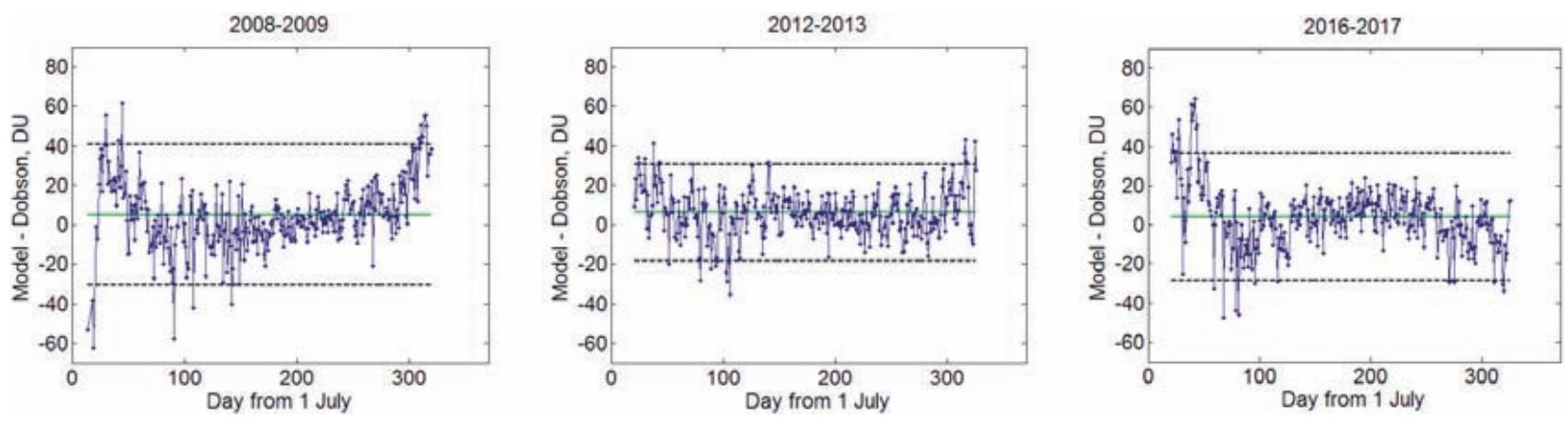

Fig. 4. Differences between the models obtained from OMI measurements, and Dobson daily values. Mean values and double standard deviations are displayed by green and black horizontal lines respectively
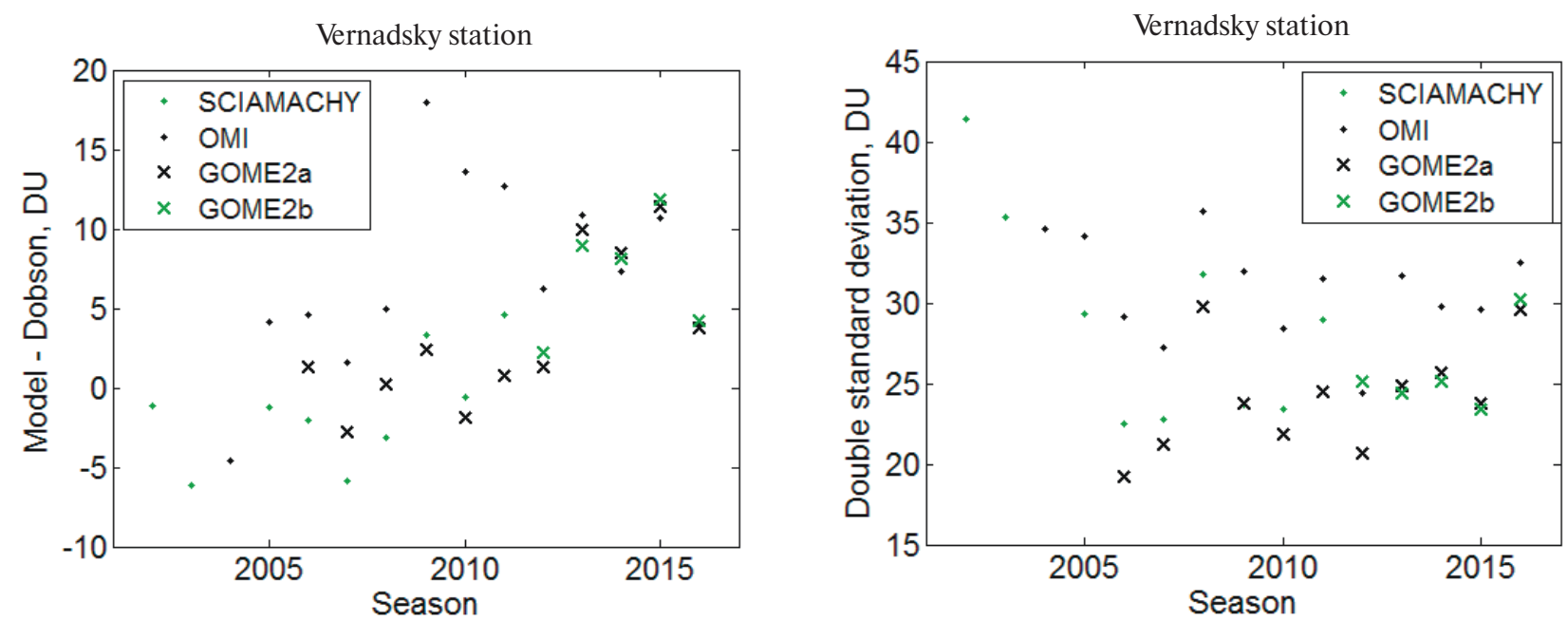

Fig. 5. (left) Model-Dobson differences averaged for observational season (it begins from July); (right) double standard deviations of the differences from their seasonal mean. Model data on 18 UT are utilized 
were between 250 and 400 DU with relatively low ones in April and August. Maximal monthly means reached 400 DU in October and November that is similar in general to the typical spring ozone maximum in the Northern mid- and high latitudes. At this, the Northern Hemisphere maximum was higher and more durable but these discrepancies were not crucial.

Later, from the early 1980s, the so-called ozone hole (Farman et al., 1985) developed with monthly total ozone decrease from 300-350 DU in the pre-ozone hole years to 150-200 DU. The sharp decrease cover time range to the mid- or late 1990s with the following stabilization. Total ozone changes in southern summer and autumn were not so drastic. The ozone hole phenomenon causes a respective growth of ultraviolet radiation intensity on the surface. Ozone hole level is defined as 220 DU corresponding to the values which were not observed before the 1980s (Fig. 1). In the last years, ozone hole is observed at Vernadsky station during September-November. Low values are registered not during the whole spring due to location of the station in the edge part of the polar stratospheric vortex. As a result, planetary wave activity influences total ozone content with noticeable variations (right part of Fig. 1).

The seasonal changes in total ozone are more uniform after the ozone hole development. The total ozone values slowly decrease up to late autumn. Significant variations are not observed during this period similarly to the typical mid-latitude ozone cycle. Before the winter gap in the observations, total ozone is close to $250 \mathrm{DU}$ with some long-term diminution. Rarely, separate values higher 300 DU should be observed. Fig. 1 includes several very large values in the 2003/2004 observational season but they are obtained with the method using light from the full Moon which cold be not so reliable as traditional Direct Sun and Zenith measurements.

\section{RESULTS}

\section{Total ozone over the Antarctica in spring}

Satellite observations allow obtaining near-global ozone distribution. The data should be processed to retrieve monthly distributions. The Nimbus-7 $(1979,1991)$ and OMI (2014) monthly means in the middle and high southern latitudes are presented in Fig. 2. They indicate main steady features in the Antarctic ozone distribution. The satellite measurements demonstrate the ozone hole deepening in the 1980s and 1990s with the following stabilization from the late 1990s (Grytsai et al., 2017). Significant interannual variations exist and ozone hole is stretched into the Atlantic longitudinal sector due to quasi-stationary planetary wave impact (Grytsai et al., 2007).

The 1979 October data exhibit monthly values exceeding the ozone hole level by several tens DU even in the inner part of the polar stratospheric vortex. Location of the ozone minimum is asymmetrical in its longitudinal position shifted to the South American longitudinal sector. A wide region with high ozone levels (400 DU and larger) covers the latitudes of $45-70^{\circ} \mathrm{S}$, this phenomenon is sometimes described as 'collar'.

The plots for 1991 and 2014 present the ozone hole conditions, which are usual for the last three decades. The ozone hole area is equal to many millions $\mathrm{km}^{2}$ even at the averaging, its inner parts are characterized by TOC of 150-200 DU and lesser. The ozone hole is evidently elongated to the Atlantic longitudinal sector, and location of the quasi-stationary minimum in the ozone distribution was earlier studied (Grytsai et al., 2007, 2017; Ialongo et al., 2012).

\section{Dobson measurements and satellite overpasses}

The OMI overpasses include measurements with distance from Vernadsky station not exceeding $100 \mathrm{~km}$ (http://www.temis.nl/protocols/O3total.html, Veefkind et al., 2006). They were compared with groundbased Dobson data for the same day. The similar study for 1996-2005 period has been provided by authors on the base of TOMS data (Kravchenko et al., 2009). In the recent analysis the total ozone from both the data series is presented in Fig. 3. Vernadsky station climate conditions strongly limit a number of Direct Sun measurements, which are of the best quality among all types of Dobson measurements. Respectively, Zenith Cloud data predominate. Zenith Cloud Dobson and OMI data usually do not exhibit systematical deviations except the beginning of observational season with high solar zenith angles as the example 
for the 2016-2017 season exhibits. In this time range, Dobson data are relatively lower. An opposite pattern was realizes during the summer season.

Discrepancies between ground-based and satellite measurements could be caused by both real differences and observational errors. Real differences are connected with spatial and temporal distinctions in the measurements. Overpasses are taken at distances that don't exceed $100 \mathrm{~km}$, and time range between the groundbased and satellite observations is to several hours. Under typical mid-latitudes, these distinctions are not crucial (Grytsai and Milinevsky, 2013). The situation could be opposite in separate cases of the sharp total ozone gradient, in particular while observational station is located near an edge of the ozone hole.

Observational errors are usually conditioned by restrictions in the algorithms used. For Dobson measurements, there is influence of the light scattered within the instrument, uncertainties in the ozone absorption coefficients, quality of the statistical approximations which are necessary for zenith observations (Basher, 1982; Redondas et al., 2014). Quality of the satellite measurements is limited by impact of clouds and underlying surface that makes the corresponding algorithm more complicated relative to the ground-based one. Despite many factors increasing differences between satellite and ground-based measurements, typical values of the differences are below $3 \%$ (nearly 10 DU, Fioletov et al., 2008). Respectively, the majority of the Vernadsky station data are within the range of distinctions on OMI overpasses.

\section{Comparison between the model and ground-based data}

To study quality of the ground-based and satellite measurements over Vernadsky station, Dobson data were compared with the data of OMI, GOME2a, GOME2b and SCIAMACHY (http://www.temis.nl/protocols/ O3global.html, Eskes et al., 2003). Data of the satellite instruments have covered time range from the 2002-2003 Vernadsky station observational season. In particular, models calculated from the satellite data were used for comparison with results of the Dobson measurements. The model values are calculated with a 6-hour step for 00, 06, 12, and 18 UT. The 18 UT data were considered as the closest in time to (14 LT) to the Vernadsky station measurements. Examples of the seasonal changes in the 'OMI model - Dobson' differences are presented in Fig. 4.

Fig. 4 exhibits that typical discrepancies between OMI model and Vernadsky Dobson daily means are mainly in the range of \pm 20 DU. Larger deviations are rare, and they are observed predominantly on the beginning and at the end of the observational season. In principle, deviations between the ground-based and satellite ozone data could be conditioned by many causes. Partially, total ozone is measured in a few different space points and different time moments therefore it is not completely equal. Besides, distinct algorithms are utilized in the ground-based and satellite measurements. Of course, the algorithms have different precision and own restrictions. In our case, errors increase at high solar zenith angles. Dobson total ozone values are predominantly lesser that could be connected with worse quality of the Dobson measurements at low intensity of solar radiation (Basher, 1982). In the same time, large deviations during the ozone hole development should be conditioned by measurements at the distances in tens kilometers. In the edge region of the ozone hole, these values should have a significant meridional gradient.

Seasonal means and standard deviations for the model-Dobson differences were calculated (Fig. 5). The OMI model exhibits worse correspondence with Vernadsky station Dobson data that is seen from higher standard deviations and large mean differences during separate years, in particular 2009-2010. Last four analyzed seasons are characterized by a relative total ozone underestimation by Dobson reaching 4-12 DU for seasonal mean. It is interesting that three models (OMI, GOME2a, GOME2b) show very similar differences with Dobson spectrophotometer data for these seasons. The models based on the GOME2a and GOME2b also have very close double standard deviations with Dobson data.

\section{CONCLUSIONS}

According to analysis the Dobson and satellite total ozone column data over Faraday/Vernadsky station have shown the total ozone decrease during the 1980s1990s (mainly in spring) with a following stabilizaISSN 1727-7485. Ukrainian Antarctic Journal. 2018, № 1(17) 
tion since year 2000. Comparison between the ground-based data and models calculated from satellite measurements indicates better correspondence of the Dobson and GOME2 results relatively the OMI ones. There are evidences that the individual Dobson measurements underestimate to some degree total ozone on the beginning of observational season at high solar zenith angles and the low total ozone values. The analyzed satellite and ground-based observations near Vernadsky station have supported a conclusion about hiatus in ozone decrease and stabilization in the ozone hole characteristics during the last two decades. Comparison of the total ozone values obtained by different methods allows evaluating their quality under different solar zenith angles and atmospheric conditions. The typical discrepancies between the Ozone Monitoring Instrument (OMI) model and the Vernadsky station Dobson daily means are mainly in the range of $20 \mathrm{DU}$. Larger deviations are rare and are observed predominantly on the beginning and at the end of the observational season.

Acknowledgments. We acknowledge the TEMIS ESA service for data at http://www.temis.nl/protocols/O3total.html, the World Ozone and Ultraviolet radiation Center (http://wo udc.org); the British Antarctic Survey (https://legacy.bas.ac.uk/met/jds/ozone/index.html) and State Institution National Antarctic Scientific Center, Ministry of Education and Science of Ukraine (http:// uac.gov.ua). We thank all winterers of Faraday/Vernadsky station for their enormous efforts in providing continuous ozone measurements. This work was partly supported by the State Institution National Antarctic Scientific Center of Ukraine, by the project of Taras Shevchenko National University of Kyiv, No. 19BF05108, and by College of Physics, International Center of Future Science of Jilin University.

\section{REFERENCES}

1. Basher, R. E. 1982. Review of the Dobson Spectrophotometer and its accuracy. Springer Netherlands, 387-391.

2. Chipperfield, M. P., Bekki, S., Dhomse, S., Harris, N. R. P., Hassler, B., Hossaini, R., Steinbrecht, W., Thiéblemont, R., and Weber, M. 2017. Detecting recovery of the stratospheric ozone layer. Nature, 549(7671), 211. doi: $10.1038 /$ nature23681.
3. Chipperfield, M. P., Dhomse, S., Hossaini, R., Feng, W., Santee, M. L., Weber, M., Burrows, J. P., Wild, J. D., Loyola, D., Coldewey-Egbers, M. 2018. On the cause of recent variations in lower stratospheric ozone. Geophysical Research Letters, 45. doi: 10.1029/2018GL078071.

4. Eskes, H. J., Van Velthoven, P. F. J., Valks, P. J. M., and Kelder, H. M. 2003. Assimilation of GOME total-ozone satellite observations in a three-dimensional tracer-transport model. Quarterly Journal of the Royal Meteorological Society, 129(590), 1663-1681. doi: 10.1256/qj.02.14.

5. Farman, J. C., Gardiner, B. G., and Shanklin, J. D. 1985. Large losses of total ozone in Antarctica reveal seasonal clox/nox interaction. Nature, 315(6016), 207. doi: 10.1038/315207a0.

6. Fioletov, V. E., Labow, G., Evans, R., Hare, E. W., Köhler, U., McElroy, C. T., Miyagawa, K., Redondas, A., Savastiouk, V., Shalamyansky, A. M., et al. 2008. Performance of the ground-based total ozone network assessed using satellite data. Journal of Geophysical Research: Atmospheres, 113(D14). doi: 10.1029/2008jd009809.

7. Gottwald, M., H., Bovensmann, G., Lichtenberg, S., von Bargen S., N. A., Slijkhuis, A., Piters, R., von Savigny M., H. C., Buchwitz, A., Kokhanovsky, A., Richter, A., Rozanov, T., Holzer-Popp, K., J.-C., B., Lambert, J., Skupin, F., Schrijver, W. H., and Burrows, J. 2006. SCIAMACHY, monitoring the changing earth's atmosphere, German Aerospace Center (DLR), Remote Sensing Institute (IMF), Report No. 167.

8. Grytsai, A. V., Evtushevsky, O. M., Agapitov, O. V., Klekociuk, A. R., and Milinevsky, G. P. 2007. Structure and long-term change in the zonal asymmetry in Antarctic total ozone during spring. Annales Geophysicae, 25(2), 361374. doi: 10.5194/angeo-25-361-2007.

9. Grytsai, A., Klekociuk, A., Milinevsky, G., Evtushevsky, O., and Stone, K. 2017. Evolution of the eastward shift in the quasi-stationary minimum of the Antarctic total ozone column. Atmospheric Chemistry and Physics, 17(3), 17411758. doi: 10.5194/acp-17-1741-2017.

10. Grytsai, A. and Milinevsky, G. 2013. SCIAMACHY/Envisat, OMI/Aura, and ground-based total ozone measurements over Kyiv-Goloseyev station, International Journal of Remote Sensing, 34(15), 5611-5622. https://doi.org/ 10.1080/01431161.2013.794988.

11. Ialongo, I., Sofieva, V., Kalakoski, N., Tamminen, J., and Kyroa, E. 2012. Ozone zonal asymmetry and planetary wave characterization during Antarctic spring. Atmospheric Chemistry and Physics, 12(5), 2603-2614. doi: 10.5194/ acp-122603-2012.

12. Kravchenko, V., Evtushevsky, A., Grytsai, A., Milinevsky G., and Shanklin, J. 2009. Total ozone dependence of the difference between the empirically corrected EP-TOMS and high-latitude station datasets, International Journal of Remote Sensing, 30:15-16, 4283-4294, doi: 10.1080/ 01431160902825008.

13. Kuttippurath, J., Lefevre, F., Pommereau, J.-P., Roscoe, H. K., Goutail, F., Pazmino, A., and Shanklin, J. D. 2013. 
Antarctic ozone loss in 1979-2010: first sign of ozone recovery. Atmospheric Chemistry and Physics, 13(3), 16251635. doi: 10.5194/acp-13-1625-2013.

14. Redondas A., Evans R., Stuebi R., et al. 2014. Evaluation of the use of five laboratory-determined ozone absorption cross sections in Brewer and Dobson retrieval algorithms. Atmospheric Chemistry and Physics, 14, 1635-1648. https://doi.org/10.5194/acp-14-1635-2014

15. Siddaway, J. M., Petelina, S. V., Karoly, D. J., Klekociuk, A. R., and Dargaville, R. J. 2013. Evolution of antarctic ozone in september-december predicted by ccmval-2 model simulations for the 21st century. Atmospheric Chemistry and Physics, 13(8), 4413-4427. doi: 10.5194/acp-13-4413-2013.

16. Solomon, S. 1999. Stratospheric ozone depletion: A review of concepts and history. Reviews of Geophysics, 37(3), 275-316. doi: 10.1029/1999rg900008.
17. Stolarski, R. S., Krueger, A. J., Schoeberl, M. R., McPeters, R. D., Newman, P. A., and Alpert, J. C. 1986. Nimbus 7 satellite measurements of the springtime Antarctic ozone decrease. Nature, 322(6082), 808-811. doi: 10. 1038/322808a0.

18. Veefkind, J. P., de Haan, J. F., Brinksma, E. J., Kroon, M., and Levelt, P. F. 2006. Total ozone from the ozone monitoring instrument (OMI) using the DOAS technique. IEEE Transactions on Geoscience and Remote Sensing, 44(5), 1239-1244. doi: 10.1109/tgrs.2006.871 204.

19. Waugh, D. W. and Randel, W. J. 1999. Climatology of Arctic and Antarctic polar vortices using elliptical diagnostics. Journal of the Atmospheric Sciences, 56(11), 15941613. doi: 10.1175/1520-0469(1999)056<1594: coaaap > 2.0.co;2.

\section{А. В. Грицай ${ }^{1}$, Г. П. Міліневський ${ }^{1,2,3, ~ *, ~ О . ~ I . ~ І в а н і г а ~}{ }^{1}$}

${ }^{1}$ Київський національний університет імені Тараса Шевченка,

01601, м. Київ, вул. Володимирська 64/13

2 Державна установа Національний антарктичний науковий центр МОН України, 01601, м. Київ, бульвар Тараса Шевченка, 16

${ }^{3}$ Коледж фізики, Міжнародний центр науки майбутнього, Цзилінський університет, 130012, м. Чанчунь, Китай, вул. Цянцин 2699

* Corresponding author: genmilinevsky@jlu.edu.cn, genmilinevsky@gmail.com

\section{ЗАГАЛЬНИЙ ВМІСТ ОЗОНУ НАД АНТАРКТИЧНОЮ СТАНЦІЕЮ «АКАДЕМІК ВЕРНАДСЬКИЙ»: НАЗЕМНІ ТА СУПУТНИКОВІ ВИМІРЮВАННЯ}

РЕФЕРАТ. Мета. Проаналізувати зміни загального вмісту озону над антарктичною станцією «Академік Вернадський» (до 1996 р. станція Фарадей) за довгостроковими наземними та супутниковими рядами даних. Дослідити розбіжності між даними різних інструментів. Методи. Візуалізація даних з подальшим аналізом та статистичною обробкою рядів загального вмісту озону за вимірюваннями на спектрофотометрі Добсона на станції «Академік Вернадський» та супутниковими інструментами OMI, GOME2a, GOME2b та SCIAMACHY. Результати. Супутникові та наземні вимірювання загального вмісту озону в стратосфері над станцією «Академік Вернадський» підтвердили стабілізацію озонового шару з початку 2000-х років. Британські спостереження на станції Фарадей продемонстрували, що максимум загального вмісту озону протягом 1950-1970 рр. спостерігався навесні, аналогічно північній півкулі, а різке зниження загального вмісту озону протягом серпня-жовтня 1980-1990рр. суттєво змінило загальний сезонний озоновий цикл і $€$ наслідком впливу озонової діри. В даній роботі було проаналізовано супутникові та модельні дані на основі супутникових вимірювань. Було показано, що типові розбіжності між моделлю озонового моніторингу (ОМІ) та щоденними вимірюваннями на спектрофотометрі Добсона станції «Академік Вернадський» знаходяться в межах близько 20 DU. Великі відхилення зустрічаються рідко, і спостерігаються переважно на початку і в кінці спостережного сезону. Також були розраховані сезонні середні та стандартні відхилення відмінностей моделей від спостережень на спектрофотометрі Добсона, які свідчить про гіршу відповідність моделі ОМІ з даними спектрофотометра Добсона протягом окремих років, зокрема 2009-2010 років. Висновки. Як наземні, так і супутникові вимірювання загального вмісту озону в стратосфері над станцією Фарадей/«Академік Вернадський» продемонстрували загальне зменшення вмісту озону протягом 1980-1990рр. навесні з подальшою стабілізацією починаючи з 2000-го року. Порівняння між наземними даними та моделями на основі супутникових вимірювань, свідчить про кращу відповідність результатів вимірювань на спектрофотометрі Добсона та GOME2 відносно порівняння з даними ОМІ. Визначено, що індивідуальні вимірювання на спектрофотометрі Добсона в деякій мірі недооцінюють загальний вміст озону на початку спостережного сезону, коли сонячні зенітні кути досить великі, а загальний вміст озону є низьким.

Ключові слова: загальний вміст озону, антарктична станція «Академік Вернадський», спектрофотометр Добсона, супутникові вимірювання, порівняння даних. 